\title{
Zdravstvena nega pacijenata sa nutritivnom gastrostomom
}

Vesna Nikolić, vms

Kbc "Bežanijska Kosa”

Sažetak: Nutritivna gastrostoma je čest oblik enteralne ishrane kod onih bolesnika kod kojih je iz bilo kog razloga onemogućena ishrana per os. Izvodi se kroz mali rez na prednjem trbušnom zidu u srednjoj liniji odmah iznad umibilikusa. U zavisnosti od zdravstvenog stanja nutritivna gastrostoma može biti privremena i trajna. Nutritivna gastrotoma se postavlja kod onih pacijenata kod kojih je privremeno ili trajno onemogućeno gutanje zbog čega nema unosa kvalitetne hrane, odnosno hrane potrebne za normalan dnevni obrok. Na taj način i nutritivna gastrostoma obezbeđuje privremeno ili dugoročno rešenje za ishranu.

Od posebne je važnosti psihička priprema kako bolesnika tako i porodice za prihvatanje ovakvog načina ishrane, koja se najčešće primenjuje kod trauma glave, malignih bolesti, neuromišićnih bolesti, neurodegenerativnih bolesti, kao i kod produžene trahealne intubacije.

Ključne reči: nega, procedure, gastrostoma, enteralna ishrana, edukacija

Abstract: Nutritional gastrostomy is a common form of enteral nutrition in those patients who, for any reason, disabled nutrition orally. It is performed through a small incision in the abdominal wall in the midline just above umibilikusa. Depending on the health status of nutritional gastrostomy may be temporary and permanent. Nutritional gastrotoma arises in those patients who have temporarily or permanently prevented from swallowing why there is no entry of quality food, that food necessary for normal daily meals. In this way the nutritional gastrostomy provides temporary or long-term solution to food.

It is particularly important to the patients psychological preparation of the family as well as to the acceptance of this type of food, that is usually applied to head trauma, malignant diseases, neuromuscular disorders, neurodegenerative diseases, as well as extended tracheal intubation.

Keywords: care, procedures, gastrostomy, enteral nutrition, education

\section{UVOD}

$\mathrm{Z}$ dravstveno vaspitni rad je jedan od osnovnih funkcija sestre u radu sa bolesnicima sa gastrostomom. Zdravstveno vaspitanje se definiše kao aktivan proces učenja i osposobljavanja pojedinca i zajednice da se koriste znanjem o psihičkom, fizičkom i socijalnom zdravlju sa ciljem da se izgradi pravilan odnos prema zdravom načinu života. Zdravstveno vaspitanje je svaka kombinacija iskustva u učenju koja omogućava dobrovoljne promene ponaša koje vode zdravlju.

Treba sagledati specifičnosti zdravstvene nege i higijensko dijetetskog režima bolesnika sa gastrostomom, kao i značaj porodice u sprovođenju higijensko dijetetskog režima. Veoma je važno da medicinska sestra zna kada i kako treba prići pacijentu, jer neretko se događa da pacijent ne prihvata takav način ishrane. Znanje i veštine medicinska sestra u takvim situacijama su od neprikosnovene važnosti.

\section{GASTROSTOMIJA}

Gastrostomija je operativni postupak za postavljanje katetera kroz mali rez na prednjem trbušnom zidu, za ishranu bolesnika. U zavisnosti od zdravstvenog stanja nutritivna gastrostoma može biti privremena ili trajna. Nutritivna gastrostoma je namenjena pacijentima koji zbog nemogućnosti gutanja privremeno ili trajno ne mogu da unose potrebne dnevne količine kvalitetne hrane i obezbeđuje im dugoročno rešenje za ishranu. Najčešće se primenjuje kod trauma glave, neuromišićnih bolesti, neurodegenerativnih bolesti, kod produžene trahealne intubacije,maligniteta jednjaka. Ukoliko pacijent ima prepreku u predelu jednjaka ili na bilo koji način ne toleriše nazogastričnu sondu, primenjuju se različite metode kojima se omogućava ishrana direktno preko želuca ili creva tj. enteralna ishrana. Enteralna ishrana zasnovana je na fiziološkim uticajima unosa hrane $\mathrm{u}$ organizam te ima brojne prednosti u odnosu na parenteralnu ishranu, posebno posle razvoja savremenih nutritivnih formula i finih infuzionih sistema. Dugotrajna pošteda organa za varenje nepovoljno deluje na neurohumoralne mehanizme digestije i očuvanje anatomsko-funkcionalnog integriteta gastrointestinalne sluzokože.

Prednosti enteralne ishrane u odnosu na parenteralnu:

- Komplikacije se javljaju ređe i u blažem obliku

- Preparati za enteralnu ishranu mogu da sadrže korisne materije kao što su probiotici, prebiotici i dijetna vlakna, kojih nema u parenteralnim rastvorima.

- Enteralna ishrana je jeftinija i pacijentima obezbeđuje bolji kvalitet života.

Najvažnije kontraindikacije za eneralnu ishranu:

- Uporno povraćanje

- Opstrukcija creva-ileus

- Težak enterokolitis

- Krvarenja iz gornjih partija digestivnog trakta

- Nepristupačan gastrointestinalni trakt

- Smanjene apsortivne površine creva

- Radijacioni enteritis

- Sepsa

- Pripremanje hrane i održavanje higijene posuđa 
Posuđe i pribor koje se koriste za pripremu obroka kao i za samu ishranu mora biti hemijski čisto. O tome brine pacijent ili neko od članova porodice. Ceo obrok se izmiksira i zagreje na temparaturi od 35 - 37C. Hrana pored toga što mora da bude tečna ili kašasta, mora imati odgovarajuću hranljivu vrednost. Pacijentu se mogu i treba dati sve namernice koje koriste i drugi članovi porodice. Hrana se daje u manjim obrocima najmanje pet obroka u toku dana, a ukoliko pacijent oseća glad ili žeđ može po želji. Minimum dva litra tečnosti treba da se unese u toku dana. Preko gastrostome se mogu dati i odgovarajući napici kafa, čaj, sokovi... poslastice koje pacijent želi, kao i lekovi. Nezavisno od toga koja se hrana unosi, neophodno je poštovati pravilo da sve što je pripremljeno bude toplo, da nema previše začina, da nije ljuto i gazirano. Osnovni a za bolesnika najveća problem, ogleda se u činjenici zaobilaženja usne duplje kao mesta unosa hrane zbog prirode bolesti. Nestaje osećaj ukusa jer se receptori ovog čula nalaze na jeziku. Ovaj nedostatak koji se delimično nadoknađuje čulom mirisa, pacijenti teško podnose.

\section{SESTRINSKE INTERVENCIJE U ISHRANI}
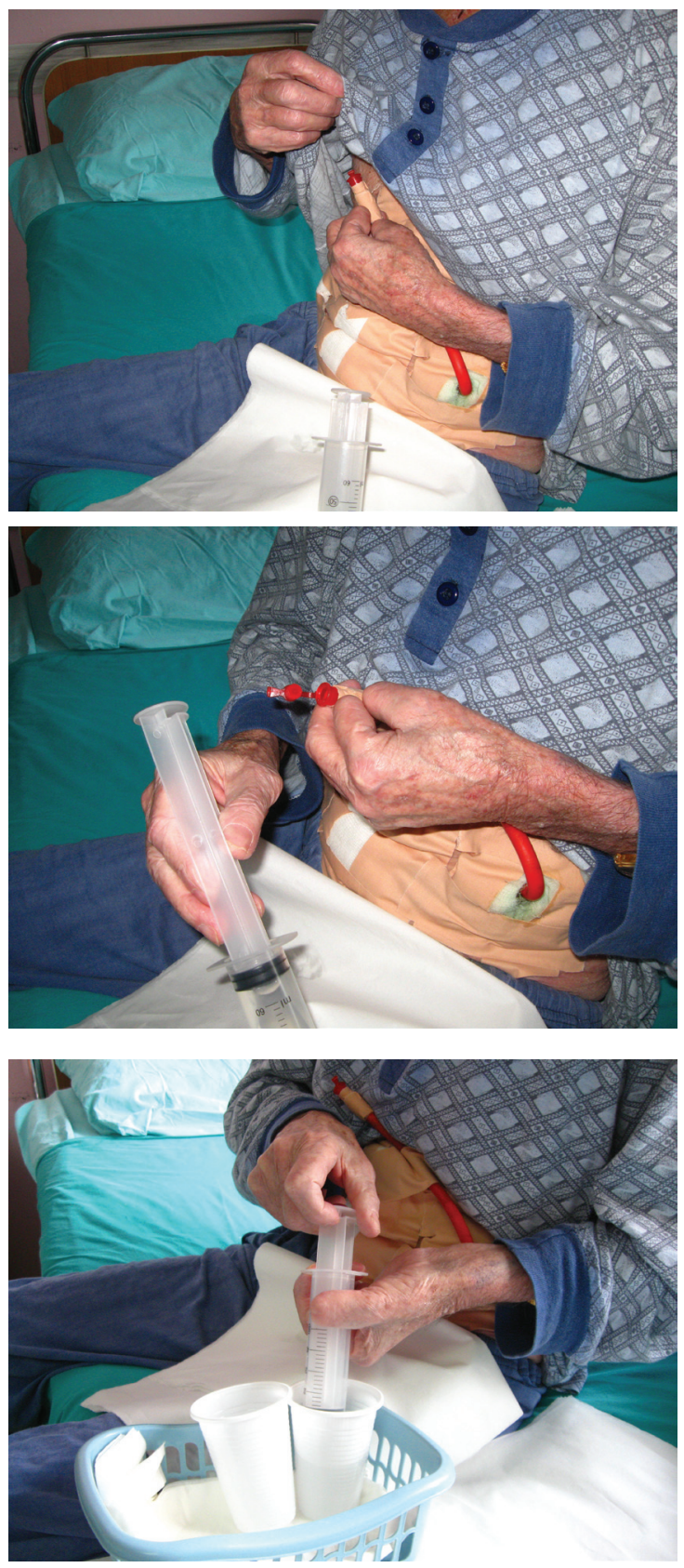

\section{PACIJENTA PREKO GASTROSTOME}

Sestra hrani pacijenta i uči ga sticanju veštine za tehniku ishrane preko gastrostome.

Pokazati pacijentu kako da klemuje sondu, skine klip i da postavi vrh šprica u sondu za ishranu.

Gastrostomu proveriti da li je prohodna tako što ćemo ubaciti 30 - $50 \mathrm{ml}$ vode ili čaja žanetom. Žanetom navući hranu i početi sa hranjenjem. Voditi računa da prilikom hranjenja ne uđe vazduh u želudac, pokazati kako se drži špric i objasniti kakve nelagodnosti stvara vazduh. Upozoriti da potpuno pražnjenje šprica može dovesti do pojave grčeva i gasova u trbuhu. Proces hranjenja trba da traje bar 15 min. a brzina protoka hrane približno prirodnom žvakanju i gutanju hrane. Reći pacijentu da obavezno na kraju hranjenja uzme $60-120 \mathrm{ml}$ vode, iz dva razloga, da bi uneo tečnost i da bi proprao sondu kako ne bi ostali ostaci hrane. Klemovati sondu i pričvrstiti za grudni koš flasterom.

Nakon usvajanja znanja i veštine u vezi hrane i načina hranjenja, sestra može dati akcenat na samoprihvatanje ovakvog načina ishrane i odnos sa socijalnom sredinom.

Objasniti pacijentu i pokazati da se gastrostoma ne vidi ispod majice i da za nju zna samo on i oni kojima on sam želi da kaže. Ukoliko ne želi da svi vide i znaju svoje obaveze van kuće i posete drugima može prilagoditi svom vremenu ishrane.

Objasniti da se može slobodno kupati, tuširati, a po završenom kupanju zameniti gazu oko gastrostome suvom.

Nagovestiti da je veoma bitno održavanje nege usne duplje bez obzira što ne unosi hranu. Pranje zuba bar dva puta dnevno, a više puta u toku dana usnu duplju isprati čistom vodom.

\section{Sestrinske dijagnoze}

1. Ishrana izmenjena, pacijent ne uzima ništa per os, hrani se preko gastrostome.

2. Smetnje sa snom zbog zabrinutosti za svoj budući kvalitet života, manifestuje se neurednim ritmom spavanja.

3. Nedostatak specifičnog znanja pacijenta i porodice, manifestuje se čestim postavljanjem pitanja.

4. Izmenjena sluzokoža usne duplje, pacijent ne uzima ništa per os zbog prirode bolesti, manifestuje se suvoćom.

5. Integritet kože oštećen usled operativnog zahvata manifestuje se crvenilom kože.

6. Povećana mogućnost nastanka infekcije u vezi plasirane IVK.

\section{Plan i program nege}

- Pranje zuba dva puta za $24 \mathrm{~h}$ i više puta ispirati usnu duplju

- Previti ranu po proceduri $\mathrm{x} 1+\mathrm{p} \cdot \mathrm{p}$

- Obrada i zamena IVK prema usvojenoj proceduri

- Ishrana preko gastrostome pacijent dobija tri glavna obroka i dve užine.

- Minimum dva litra tečnosti u toku 24h treba da unese u organizam.

- Razgovor i demostracija ishrane preko gastrostome se planira pri svakom obroku.

- Razgovor u vezi higijene, održavanja i pripremanja hrane planira se jednom u toku $24 \mathrm{~h}$.

- Razgovor sa porodicom i edukacija planira se jednom dnevno. - Porodice želi da pruži bolesniku podršku često ga posećuje, i postavlja dosta pitanja kako i na koji način mogu pomoći. 


\section{Cilj nege}

- Sluzokoža usne duplje neće biti izmenjena do kraja hospitalizacije.

- Crvenilo kože će se povući do kraja hospitalizacije.

- Neće doći do nastanka infekcije IVK do kraja hospitalizacije.

- Pacijent će biti obučen za samostalno hranjenje preko gastrostome do polaska kući.

- Pacijent će dobiti sve informacije u vezi sa gastrostomom do kraja hospitalizacije.

- Pacijent će imati bolji i kvalitetniji san do polaska kući.

- Porodica pacijenta će biti obučena i dobiće sve potrebne informacije u vezi gastrostome.

\section{Evaluacija}

- Sluzokoža usne duplje je normalnog izgleda i vlažnosti.

- Crvenilo kože se povuklo do planiranog dana otpusta.

- Nije došlo do infekcije IVK do kraja hospitalizacije.

- Pacijent je usvojio i savladao veštinu hranjenja,

- Porodica je efikasno prilagođena zdravstvenom stanju svog člana porodice.

\section{PREDLOG MERA}

Obezbediti propagadni materijal u vidu brošura, da pacijentima i porodici budu dostupne, da samim tim mogu videti šta im nije jasno, i tako tačno znati šta treba da pitaju.

Obezbediti edukativne programe u vidu demostracije za sestre koje ne rade na odeljenju hirurgije, a zbog potrebe posla treba da znaju i rade.

\section{ZAKLjUČAK}

Sestra je podrška i oslonac prvenstveno bolesniku, a potom i porodici. Ona je tu da pomogne savetom, razgovorom, toplom ljudskom reči i naravno demostracijom. Sestra mora prepoznati nivo i mogućnost usvajanja znanja, tako da informacije što adekvatnije približi pacijentovom obrazovnom nivou. Cilj je da informacije budu razumljive bolesniku.

Aktivno učenje je metod u kome učesnici aktivno učestvuju u čitavom procesu učenja, donošenjem odluka i praktičnom osposobljavanju, da naučeno primene kroz ponašanje u svakodnevnom zivotu. Aktivno učešće je snažna motivacija za njegovu praktičnu primenu.

\section{Literatura}

1. Dragović M., Gerzić Z.; Osnovi hirurgije

2. Terzić N.: Zdrastvena nega u hirurgiji, Beograd, 2006.

3. Đurica S. Interna medicina, Beograd, 2000.

4. Petrović,Z:: Bolesti jednjaka,zeluca i duodenuma;

5. Pesko P,, Randelovic T, Simic A.,Bjelovic, M., Stojkov D., Sabljak P.:Hirurgija ezofagogastroduodenuma.Hirurgija za student medicine.Medicinski fakultet Univerziteta u Beogradu, Beograd, 2008.

\section{Negativne pojave u kolektivu i preventivne mere (Alkoholizam, narkomanija, sekte i suicid)}

\section{Dr Mirjana Stojković lvković, specijalista psihijatrije VMC Karaburma Beograd}

Sažetak: Kolektiv predstavlja grupu ljudi udruženu radom radi zajedničkih ciljeva. Negativne pojave u kolektivu i direktno, oštecuju somatsko i psihičko zdravlje, i indirektno, stvarajuci konflikte, utiču na pojedinca i onemogućuju njegovo funkcionisanje u svim sferama zivota. Konflikti su praćeni psihičkom napetošću, uznemirenošću, izazivaju stres i depresiju sto dovodi do pojave psihosomatskih poremećaja. Posledice su velike: brojna bolovanja, odsustvovanja sa posla, gubitak radne sposobnosti, beg iz kolektiva, suicid. Sve ovo neminovno dovodi do dezorganizacije rada u kolektivu. Zbog toga se sprovode preventivne mere.

U radu su izneta naša iskustva u ranom otkrivanju, kontroli i rešavanju eventualnih negativnih pojava u vojnoj sredini.

Cilj rada je da se prikaže prevencija nastanka negativnih pojava i značaj edukacije zaposlenih.

Ključne reči: alkoholizam,narkomanija, sekte, suicid, prevencija

Abstract: Collective is a group of people who work together to achive a common objective. Negative phenomena in the collective directhy damage somatic and psychological health and indirecthy the occurance of conflicts affect the individual discrupting functioning in all spheres of life. Conflicts caused by stress and depression are accompanied bypsychological sunspence and anxiety which head to the occurance of psychosomatic disorders. The consequences are severe: many sick days, absence from work, loss of working capacity, escapefrom the collective, suicide. Il this inevitably leads to desorganization of work in a group.

This paper present our experiencies in the early detection, control and solving negative effects in the military service.

The aim of this work is to present preventive measures, actually the prevention of negative efects and the importance of education of the employees.

Keywords: alcoholism, drog addiction, suicid, sect, prevention 